\title{
FOOD INSPECTION AT PORTS OF ENTRY.
}

By W. F. DEARDEN, M.R.C.S., I.R.C.P., D.P.H., Medical Officer of Health, Port of Manchester.

FTER hanging fire during two sessions of Parliament, a Bill with the A direct object of assigning to all Port Sanitary Authorities in England and $W$ ales the duty of inspecting imported food stuffs received the Royal Assent in September last. This Act provides that the inspection of food shall be governed by regulations to be issued by the Local Government Board. A few weeks ago I received a draft copy of these Regulations, and as the whole work of food inspection will be regulated by them in their final form, the proper course to pursue will be to consider, from our own point of view as representatives of Port Sanitary Authorities, how they will be likely to fulfil their object.

Should anyone want to find justification for the inspection of foodstuffs at the Port of Entry into the United Kingdom, he can readily find this by examining the "Annual Statement of Trade," published by the Board of Trade. The returns for 1907 are not yet available, but those that are available are sufficient for the purpose. The value of foreign foods imported during $1906^{\circ}$ was, in round figures, assessed at $£ 200,000,000$, and that this amount has not reached finality is shown by the fact that in five years the value has increased by about $£ 30,000,000$. The value of food stuffs brought into the principal ports in England and Wales during 1906, was as follows :-

$\begin{array}{lrrllr}\text { London } & \ldots & \mathfrak{f} 72,702,835 & & \text { Southampton } & \mathfrak{f} 7,252,985 \\ \text { Liverpool } \ldots & 52,415,178 & & \text { Manchester } & 5,634,009 \\ \text { Hull } & \ldots & 17,429,305 & \text { Newcastle } & \ldots & 5,235,078 \\ \text { Harwich } & \ldots & 8,824,483 & \text { Grimsby } & \ldots & 3,868,395 \\ \text { Bristol } & \ldots & 8,367,360 & \text { Cardiff } & \ldots & 2,303,355\end{array}$

It is, therefore, apparent that we are dependent upon foreign countries for our means of subsistence, and surely this has now reached a sufficient pitch for us to take in hand means of insuring to the public 
that such food is of a proper quality, and free from risk of communicating disease.

$\mathrm{U}_{\mathrm{p}}$ to the year 1906, the sinitary authority of the Port of London was the only Port authority which had power to inspect these imports, and the gain to the public by the exercise of this power has been amply shown in the Anuual Reports of Dr. H. Williams, the Merlical Officer of Health. In this same year, the Manchester Port Order was amended by giving power to make these inspections, and the work was commenced in March of last year. Shortly after the Local Government Board inquiry, on the Manchester application, had been held, the "Jungle" scandal in America was brought prominently before the public, and there is no doubt that this made our application more secure, during the subsequent fight which took place in Parliament. But hostility to the Manchester Order was not founded on any objection to a system of food inspection at the port of entry, the contention being that Manchester should not be singled out for these powers when all other ports, excepting London, were open for any class of goods to be brought in. Although this argument was not held to be sufficient reason for refusing the Manchester application, the justice of it, so far as other ports were concerncd, was recognised, with the result that the "Public Health (Regulations as to Food) Act, 1907," was pushed through in due course.

Although the amount of food stuffs imported into Manchester is small compared with that brought into the port of London, the first year's administration of food inspection shewed the results to be on exactly the same lines as at the larger port. During this period 260 tons of food stuffs of many kinds were condemned as unfit, and from my experience of the condition of the articles in question, I can safely say that the public have very much benefited thereby.

In dealing with the draft Rergalations issued by the Local Government Board, I have thought it would be best to discuss them from the point of view of past experience in supervising food inspection, and to shew the manner in which they will modify present procedure. By their Order the Manchester Port Authority administer the food clauses of the Public Health Act of 1875, and the Amendment Act of 1890 , but as power was given in the Order itself to inspect articles of food " on a ship, or brought by a ship within the Authority's jurisdiction," it has been shewn, through a test case, that we have in addition definite power over goods in transit. To the Port of London Authority was assigned the food clauses of the Public Health (London) Act, which, in addition to ordinary powers, enables prosecutions to be taken in the case of goods deposited for the 
purpose of sale or of preparation of sale. Apart from the effect which the difference in powers must necessarily have, the mode of procedure at the ports of London and Manchester can be taken as practically the same.

The Local Government Board has published two sets of draft Regulations, one concerned with general fond inspection, and the other with inspection of foreign meats as a special class.

\section{General Regulations.}

After a careful perusal of these the impression gained is that Port Authorities generally will start their food inspection on a better basis than was the case with us in Manchester, the new powers being much better defined and a distinct improvement on those we have had to work under. At present the articles to be examined must be intended for luman consumption, but in future, articles commonly used for the food or drink of man will be deemed to be intended for this purpose unless the contrary be proved. The Manchester power of inspecting articles of food on a vessel or in a warehouse within the Authority's jurisdiction is made universal. The powers of inspection, etc., are assigned to the Medical Officer of Health, but the Authority will be able, with the consent of the Local Government Board, to appoint a deputy Medical Officer and Inspectors to exercise such of the powers as they think fit; the Inspectors being required to act under the direction of the Medical Officer of Health.

Although examinations occasionally take place on a ship, the inspections in warehouses are the principal concern to an authority. At present my Inspecting Officer, being satisfied by sample that a certain proportion of a consignment is likely to turn out unsound, serves a notice of seizure upon the wharfinger in charge, and obtains the name and address of the owner for further notification. The Ship Canal Co., and the shipping firms having warehouses of their own, have agreed not to allow any of these gcods so seized to be taken away without the consent of the Inspector or myself. The opening up of the rest of the consignment is then taken in hand by the owner, at his own expense, the authority being simply responsible for the inspection. In future the inspecting officer will be able to go on with his examination at once, simply calling upon those in charge of the ship or warehouse to unpack or uncover as much of the goods as may be necessary for the purpose of examination. Whether the owner of the goods or the Port Sanitary Authority is to pay the expense of this preparation for examination is not stated. My own view is that the wharfinger must provide the labour on demand, the cost being borne by the owner. In the rare instances where labour of this kind has been 
required by the authority it has always been furnished, but only upon a signed requisition for labour being handed in by an officer of the authority, and the authority being made responsible for the charge. On the unsound articles being separated, the inspecting officer is at present supposed to seize these and at once carry them away to be dealt with by a magistrate, though he does not always do so on account of his arrangements with the occupiers of the warehouses. Under the Regulations he will be able to either move the articles or give notice to the person in charge that such must not be moved until dealt with by a justice, or until permission be obtained from the medical officer of health.

If the articles be surrendered for destruction, or the medical officer agrees to their being utilised for some satisfactory purpose, other than human food, they can, as at present, be removed under supervision for that purpose. The justice will deal with the unsound articles as now, if satisfied that they are unfit for human consumption, and it has not been proved to him that the sale for human consumption was not intended. If it be proved to the justice that the articles are not intended for sale for human consumption an order will be made dismissing the complaint, but setting forth such particulars of the goods as will suffice to identify them, along with the names, descriptions, and abodes, of the importer and the person who is to take delivery. A copy of this document will have to be furnished to the authority. Where an owner raises the contention that in article is not imported for purpose of sale for human consumption, and he has not satisfied the medical officer as to the purpose for which it will be used, it will presumedly be necessary to give him a chance to appear before the magistrate when a condemnation order is being sought for. The inspecting officer is to be empowered to take samples, but there is nothing to indicate that the authority will be expected to pay for these. In practice, however, most firms are willing to supply any samples required, though in a few instances my authority has paid the value.

The medical officer of health will have power to detain any consignment for any time not exceeding 48 hours, or for longer, by arrangement with the owner, if special procedure should be regarded as necessary for the purpose of the examination. This detention is apparently intended to allow time for the results of chemical and bacteriological examinations to be obtained. It should also enable the inspecting officer to detain, pending the decision of the medical officer on the conclition of samples which he might have submitted to him. The utility of this Regulation will depend upon the elasticity which will be allowed to the medical officer 
in deciding as to what may be considered as "special procedure" necessary for the examination of articles of food. The quality of food consignments generally is gauged on a percentage examination, and large quantities are passed as sound on this. If the percentage, on the other hand, proves unfavourable, a complete examination becomes a necessity, and from my own experience I should certainly class such as "special procedure." Notices served in connection with the Regulations may be sent through the post.

Provision is made for granting search warrants, but as the penalty for disobeying any of the Regulations is $£ 100$, I should not anticipate that these will be extensively required.

Specific direction is given in the Regulations to keep a record of all articles of fuod destroyed or otherwise disposed of. Although such a direction does not form a part of the Manchester Port Order of 1906, a record of every particular in connection with seizures, destructions and disposals has been kept in my office, and on several occasions has been utilised by interested parties as a trustwortly reference in case of doubt or dispute.

The Regulations should come into operation on the 1st September next, and will be applicable to all port sanitary authorities in England and Wales.

\section{Foneigix Meit Regulations.}

The reason for treating foreign meat under a separate set of Regulations can readily be appreciated on perusal of a recent Report by Dr. G. S. Buchanan, of the Local Government Board, on "Certain Imported Meat Foods of Questionable Wholesomeness." This publication you are doubtless familiar with, and you will, therefore, be able to recognise at once that the Regulations are framed to deal effectively with the particular classes of meats indicated in the Report as requiring stringent treatment. I think we shall all agree that scrap meat and carcases of pigs, which present nothing to an inspecting officer to indicate whether diseased or not, are better out of the country, and that such popular articles as tripe, tongues and kidneys, should not be allowed a market in England when so heavily dosed with preservatives as has been proved to be the case.

Under the Regulations foreign meat is to be tabulated under four headings. Class 1 has reference to fresh or preserved "scrap" meat which cannot be identified with any definite part of a carcase, is without bone in its natural state of attachment, and has not been converted into sausage or other compound or manufactured article; tripe, tongues or kidneys packed ${ }_{0}^{\top}$ in preservatives; severed and other edible parts of a pig, which have not been converted into ham or bacon, or are boxed without 
an official certificate. Class 2 refers to entire carcases of pigs, not prepared as bacon and ham, which are without the head in its natural attachment, and without the lympathetic glands about the throat or other parts of the carcase in their natural position. Class 3 refers to severed and other edible parts of pork, which are boxed with an official certificate impressed on the outside. The fourth tabulation, "Unclassified," refers to any meat not in any of the three classes mentioned. All kinds of meat or meat preparations coming into the country will therefore be covered under these headings.

It will be the duty of the officer of customs to ascertain the presence of foreign meat and its classification on a ship arriving in port. In the case of meat of Classes 1 and 2 he must prohibit removal until examined by the medical officer of health. The medical officer will be advised forthwith, and he or his inspecting officer will examine the meat. The officer of customs will not be required to detain meat coming under Class 3, or unclassified meat, unless he has special reasons for so doing. ${ }^{*}$ Should he do so, he will adopt the same procedure with respect to such meat as in the case of Classes 1 and 2. Should the officer of customs not place a bar against the removal of any foreign meat this will not interfere with the inspecting officer examining and dealing with such, should he come in contact with it. Should the meat come under Class 1 or 2 the inspecting officer will serve a notice in writing, forbidding the removal of the meat for any purpose other than exportation. If he is of opinion that the meat, though belonging to Class 3 or unclassified, should not be used for consumption in this country, he may give a similar notice requiring exportation, but if satisfied that it may be removed to a place of destination in England or Wales, for any other purpose than exportation, he may give a certificate to that effect.

The medical officer will presumably be required to send a copy of any notice for exportation to the clerk to the anthority, who must within twelve hours after receipt of the same, serve a written notice on the importer, to the effect that unless he gives a written undertaking to export the meat, at his own expense, or will be prepared to prove before a justice that the meat is not intended for sale for human consumption, the sanitary authority will order the meat to be destroyed.. Any undertaking must be given within twelve hours, or the meat will be destroyed by the authority. If an undertaking to export be given this must be executed within three

* An intimation, given from time to time by the Medical Officer of Health to the Collector of Customs, that any particular kind of meat or meat preparation will require examiuatiun should constitute a "special reason." 
days to avoid destruction. Should the importer undertake to prove before a justice that the meat is not intencled for sale for human consumption, the authority must bring the matter before a justice within twenty-four hours. Should the contention of the importer not be proved, the justice orders destruction (not exportation), but if proved, he directs the removal of the prohibition, at the same time setting forth on his order particulars of identity of the meat, the importer, and the person to whom it is to be delivered. Full particulars of the seizures and disposals are to be kept by the authority.

As it would not always be possible to export undesirable meat within the three days" limit, owing to the requisite boats not being available within this time, from the port of landing, it is to be presumed that safe custody until the proper exporting medium has been provided will be regarded as sufficient.

So far as concerns official certificates attached to foreign meats, the only ones which will be recognised will be published in the London Gazette, as satisfactorily indicating that the meat has been free from disease, and has been dressed and prepared in such a manner as to prevent any danger to the pullic from contamination. It may be noted that the only meats requiring an official certificate under the Regulations as drafted are severed and other edible parts of a pig.

These special Regulations should come into operation on 1st Nov. next.

It would without a doubt have been interesting to have retailed some of my experiences of the unsound food which I have come across in the exercise of my duties in Manchester, but I must leave room for those who have to follow. I should like to point out, however, that experience teaches me that the bulk of importers are not at all difficult to get on with when they understand the working of food inspection regulations at a port. They approve of the principle of food inspection, and have no desire to import anything unsound. They are prepared to work in harmony with the inspectors to secure prompt dealing with any of their goods under suspicion, so that there may be no unnecessary delay in delivery, and they seldom clispute the decision of an inspector as to unsomndness. The certificates of seizure given by the inspectors in exchange for surrender have, furthermore, proved a distinct advantage to these people in arranging deductions from payments to the consignor. On the other hand, those people who are importing foodstuffs of a known risky character rery soon give up the business after inspection commences. I unhesitatingly approve of the new draft Regulations. It is not to be contended, however, that they are perfect or final. I do not 
doubt that experience will show the necessity of certain alterations and additions, and that these will be given effect to from time to time, but if they are put into operation, in the present form only, they will mark a distinct advance on previous methods of dealing with unsound food. Personally I am of opinion that a necessary corollary is their extension to railway stations. Cheap water transit is largely taken advantage of for transport of foolstuffs by coasters, and as many of the articles thus carried have been in store for a considerable time, and therefore subject to deterioration, they are often found unsound. Universal inspection at ports will necessarily divert this class of traffic to the railways. It would also not be amiss to have our home food products under supervision at railway stations, and as Glasgow and Iseith are not affected by the Regulations they provide good openings for risky foreign foodstuffs to be landed and brought over the horder by rail. But this feature, important though it is, should not deter us from heartily approving of the facilities to be given for inspection at our ports. The Local Gorernment Board deserve every credit for the pertinacity displayed in pushing forward with their Regulations. That it has been no easy matter to frame them I know, but now that they are issued I trust that self interest will not be allowed to bring ahout any mutilation before they appear in their final form.

Dr. H. Willians (Port of London) said that he thought the new regulations were an earnest effort to deal with a difficult problem. The Unsound Regulations, 1st series, legalised the procedure which had been practised in the Port of London for many years. Attention was drawn to the fact that notice liad to be given to the sanitary authority who would issue certain notices. That meant delay, as it would be necessary to call a special meeting of the authority.

DR. F. M. WILLLAMs (Plymouth) asked whether the forecastle was inspected before transhipment from ship to ship at port of entry. 